Please share your stories about how Open Access to this article benefits you.

\title{
A horseshoe crab (Arthropoda: Chelicerata: Xiphosura) from the Lower Devonian (Lochkovian) of Yunnan, China
}

\author{
by J. C. Lamsdell, J. Xue, and P.A. Selden
}

date

This is the published version of the article, made available with the permission of the publisher. The original published version can be found at the link below.

James C. Lamsdell et al (2013). A horseshoe crab (Arthropoda: Chelicerata: Xiphosura) from the Lower Devonian (Lochkovian) of Yunnan, China. Geological Magazine 150:367-370.

Published version: http://dx.doi.org/10.1017/So016756812000891

Terms of Use: http://www2.ku.edu/ scholar/docs/license.shtml 


\title{
A horseshoe crab (Arthropoda: Chelicerata: Xiphosura) from the Lower Devonian (Lochkovian) of Yunnan, China
}

\author{
JAMES C. LAMSDELL*†, JINZHUANG XUE $\ddagger \&$ PAUL A. SELDEN*§ \\ * Department of Geology, University of Kansas, 1475 Jayhawk Boulevard, Lawrence, Kansas 66045, USA \\ $\ddagger$ The Key Laboratory of Orogenic Belts and Crustal Evolution, School of Earth and Space Sciences, \\ Peking University, Beijing 100871, P. R. China \\ $\S$ Natural History Museum, Cromwell Road, London SW7 5BD, UK
}

(Received 29 August 2012; accepted 21 September 2012; first published online 23 October 2012)

\begin{abstract}
A single specimen of a new species of the synziphosurine Kasibelinurus Pickett, 1993 is described from the Lower Devonian (Lochkovian) Xiaxishancun Formation of Yunnan Province, China. The new species, K. yueya sp. nov., extends the geographic extent of the family Kasibelinuridae from the Australian palaeocontinent to the South China palaeocontinent, and the stratigraphic range back some $50 \mathrm{Ma}$ from Late to Early Devonian.
\end{abstract}

Keywords: palaeobiogeography, South China, Kasibelinurus, synziphosurines, Palaeozoic, palaeocontinents

\section{Introduction}

Xiphosurans are an aquatic group of chelicerate arthropods defined by the possible autapomorphies of ophthalmic ridges and an axial region of the opisthosoma (Dunlop \& Selden, 1997). Only four species exist today and are all members of the order Xiphosurida, further united by their large crescentic prosomal shield and the fusion of the opisthosomal tergites into a thoracetron. The xiphosurid fossil record extends back as far as the Ordovician (Rudkin, Young \& Nowlan, 2008; Van Roy et al. 2010), while that of their supposed stem lineage ranges from the Ordovician to the Carboniferous (Moore, McKenzie \& Lieberman, 2007; Van Roy et al. 2010). This stem lineage has, in the past, been considered a monophyletic clade with subordinal status (Eldredge, 1974), but is now considered a paraphyletic grade informally termed 'synziphosurines' (Anderson \& Selden, 1997). It consists of xiphosurans with freely articulating opisthosomal segments. The analysis of Anderson \& Selden (1997) retrieved the Australian Late Devonian synziphosurine Kasibelinurus Pickett, 1993 as the sister-taxon to Xiphosurida, united with the order by the reduction of the number of opisthosomal segments to nine (but see Section 5 below).

Here we report the discovery of a new species of Kasibelinurus from the Lochkovian Xiaxishancun Formation of Yunnan, China. This is only the second record of a horseshoe crab from China, the other being Yunnanolimulus luopingensis Zhang, Hu, Zhou, Lv \& Bai, 2009, a xiphosurid

$\nmid$ †uthor for correspondence: lamsdell@ku.edu from the Triassic of Luoping, also in Yunnan Province (Zhang et al. 2009). The discovery of the Chinese Kasibelinurus not only extends the age of the genus back some 50 million years but also shows that the South China palaeocontinent was accessible to xiphosurans prior to the Mesozoic era. This provides a further link between South China and Australia during the Devonian. These palaeocontinents were considered to be in relatively close proximity to each other in Early Devonian time (Scotese \& McKerrow, 1990) and shared a number of floral components in their fossil assemblages (Hao \& Gensel, 1998, 2001).

\section{Material and methods}

The specimen described herein was collected from the lower part of the Xiaxishancun Formation at a locality south of the Shangxishan Reservoir near Qujing city, Yunnan, SW China (see fig. 1 of Xue, 2012). It is preserved in a thin bed of greenish grey mudstone, where axes of Uncatoella verticillata Li \& Cai, 1978, a marine dasycladalean alga, were also found. The specimen was immersed under water prior to photographing in order to enhance the contrast. The photograph was taken with cross-polarized illumination. The specimen is housed at the School of Earth and Space Sciences, Peking University, P. R. China.

\section{Stratigraphy}

The Pridoli-Lower Devonian deposits are well developed in the Qujing area (see fig. 1 in Xue, 2012 for locations and details of the geology). In ascending order, the Xiaxishancun Formation, the Xitun Formation, the Guijiatun Formation and the Xujiachong Formation constitute the Cuifengshan Group (Liu et al. 2004; and see fig. 2 in Dupret \& Zhu, 2008). These four formations are generally considered to be Early Devonian in age (Li \& Cai, 1978; Cai et al. 1994), but their exact age is still a matter of controversy (Rong \& Chen, 2000; Tian et al. 2011; Xue, 2012). A Pridoli age was suggested for the Xiaxishancun Formation based on thelodont microfossil assemblages (Wang, 1997; Rong \& Chen, 2000). The palynological study by Tian et al. (2011) also suggested a Pridoli age for this formation. However, the Siluro-Devonian boundary was placed at the base of the Xiaxishancun Formation, based on other comprehensive studies of spores, conodonts (from the underlying Yulongsi Formation), ostracods, vertebrate assemblages, geochemical 


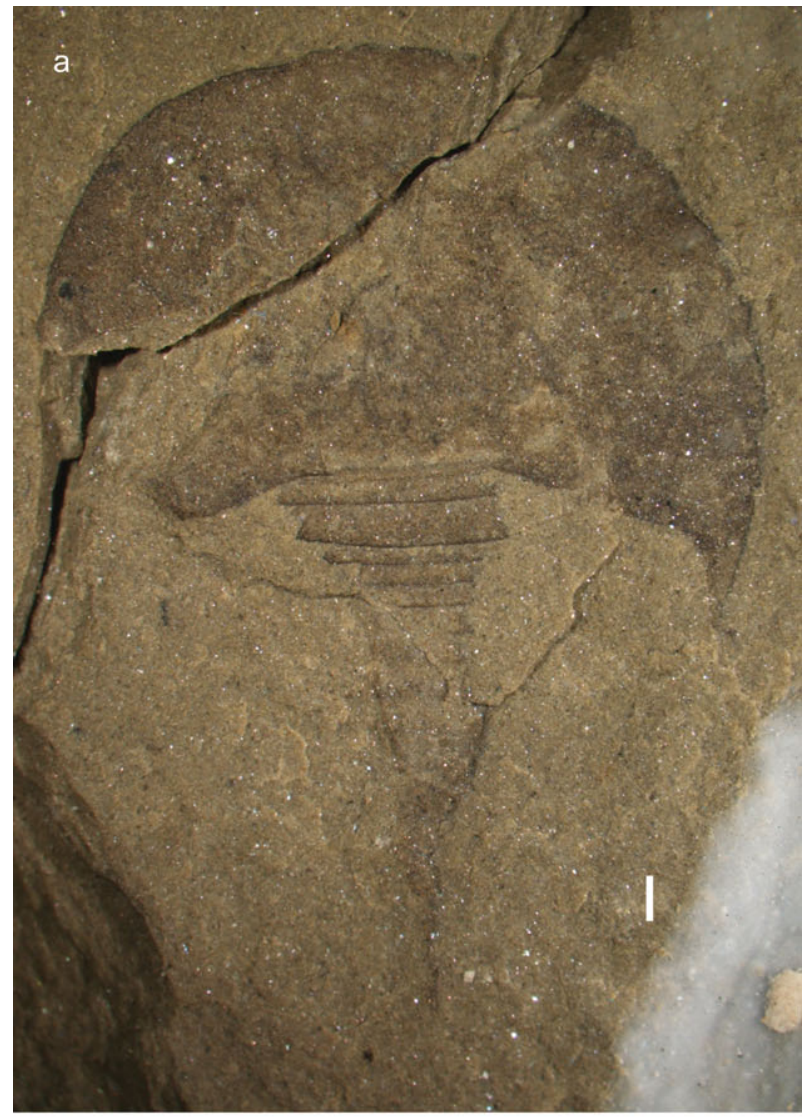

b

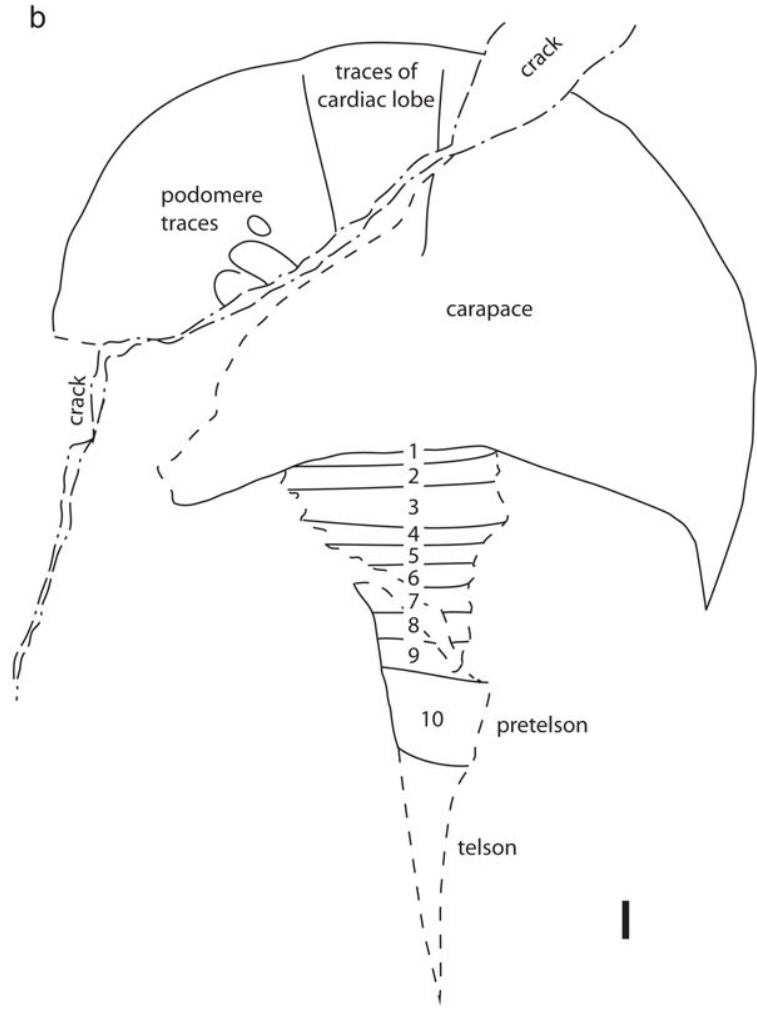

Figure 1. (Colour online) Kasibelinurus yueya sp. nov. (a) Photograph of holotype PKU-XH500. (b) Camera lucida of PKU-XH500. Solid lines show the original shape and carapace structures of the specimen, while dashed lines indicate breaks or indistinct margins where the specimen is obscured by the matrix. Scale bars represent $1 \mathrm{~mm}$. stratigraphy and others (Wang, Liu \& Li, 1992; Fang et al. 1994; Cai et al. 1994; Zhao et al. 2011), and these studies indicate that the Xiaxishancun Formation is early Lochkovian in age. Regarding our new fossil, we tentatively suggest an earliest Lochkovian age, but a Pridoli age is also possible.

The Xiaxishancun Formation is mainly composed of greyish and greenish grey siltstone, mudstone and fine sandstone in lithology, and may represent the deposits of marine tidal flats (Cai \& Wang, 1995). This formation yields abundant fossils, including land plants: Zosterophyllum sp. and Z. xishanense Hao, Xue, Liu \& Wang, 2007 (Hao et al. 2007); algae: Uncatoella verticillata, Discinella cuifengshanensis Li \& Cai, 1978 and Chovanella sp.; invertebrates: bivalves (Dysodonata), ostracods (leperditiids, beyrichiids and Cryptophyllus) (Wang, Liu \& Li, 1992), gastropods (Platystroma and Straparollus); and fish: galeaspids (Yunnanogaleaspis, Polybranchiaspis, Dongfangaspis, Laxaspis, Diandongaspis, Nochelaspis, Damaspis and Stephaspis) and antiarchs (Yunnanolepis, Heteroyunnanolepis, Chuchinolepis and Minicrania) (Zhao \& Zhu, 2010).

\section{Systematic palaeontology}

Subphylum CHELICERATA Heymons, 1901 Class XIPHOSURA Latreille, 1802 STEM XIPHOSURIDA

Family KASIBELINURIDAE Pickett, 1993 Genus Kasibelinurus Pickett, 1993

Type species. Kasibelinurus amicorum Pickett, 1993, by original designation.

Included species. Kasibelinurus yueya sp. nov.

Stratigraphical range and distribution. Devonian (Lochkovian to Famennian) of China and Australia.

Emended diagnosis. Xiphosurans with ophthalmic ridges effaced; precardiac field defined by anterior prolongations of the cardiac furrows; opisthosomal pleurae with distinct inner and outer zones; pretelson elongate (emended from Pickett, 1993).

Remarks. Pickett (1993) suggested that 'Bellinurus' alleghenyensis Eller, 1938 and 'Bellinurus' carterae Eller, 1940 may have affinity with Kasibelinurus and may be kasibelinurids, if not directly assignable to the genus. Babcock et al. (1995) reassigned Paleolimulus randalli (Beecher, 1902) to Kasibelinurus without comment based on new specimens from the Chadakoin Formation of Allegany County, New York (the original material consisted solely of carapaces). This material, however, was never fully described and, while in general outline they do resemble Kasibelinurus in having a precardiac field and opisthosomal pleurae with distinct inner and outer zones, they lack the elongate pretelson and possess ophthalmic ridges that form a double arch configuration (J. C. Lamsdell, pers. obs.), a characteristic absent in other Kasibelinurus species, and so is herein excluded from the genus.

\section{Kasibelinurus yueya sp. nov.} Figure 1

\section{Material. PKU-XH500 (holotype).}

Horizon and locality. Lower part of the Xiaxishancun Formation (early Lochkovian); south of the Shangxishan Reservoir near Qujing city, Yunnan, southwestern China.

Diagnosis. Kasibelinurus with pleural regions of posterior carapace margin angled posteriorly; third tergite enlarged. 
Etymology. Anglicized from the Chinese 月牙 (Yue Ya), meaning crescent moon, in reference to the crescentic outline of the carapace.

Description. Carapace semicircular, almost crescentic. $14 \mathrm{~mm}$ wide at broadest point, $8 \mathrm{~mm}$ long at centre. Posterior margin straight for $4 \mathrm{~mm}$ at axis, then curves posteriorly at $155^{\circ}$ before forming genal spines at the posterolateral corners of carapace. Carapace dorsal structures only faintly preserved and the lateral eye position unclear; however, diverging striations on the anterior half of the carapace (4 $\mathrm{mm}$ long, $2 \mathrm{~mm}$ apart at origin diverging to $3 \mathrm{~mm}$ apart distally) may represent the forward portion (precardiac field) of an H-shaped cardiac lobe. Radiating ridge structures on the left side of the carapace axial region occur where the carapace has broken away and may represent cross-sections of prosomal appendage podomeres. Only the axial region of the opisthosoma is preserved; ten tergites and telson present. First tergite partially covered by carapace, visible length $0.3 \mathrm{~mm}$; second tergite $0.5 \mathrm{~mm}$, third $1 \mathrm{~mm}$, fourth $0.3 \mathrm{~mm}$, fifth $0.5 \mathrm{~mm}$, sixth $0.5 \mathrm{~mm}$, seventh $0.6 \mathrm{~mm}$, eighth $0.6 \mathrm{~mm}$, ninth $0.6 \mathrm{~mm}$ and tenth (pretelson) $2 \mathrm{~mm}$. Telson lanceolate, $4.5 \mathrm{~mm}$ long, $1 \mathrm{~mm}$ wide at base.

\section{Discussion}

Kasibelinurus yueya sp. nov. (Fig. 1) shares a number of characteristics with Kasibelinurus amicorum that strongly attest to their congeneric nature, namely the enlarged pretelson, precardiac field resulting in an $\mathrm{H}$-shaped cardiac lobe and the crescentic xiphosurid-shaped carapace. The Chinese species differs in the angle of the lateral portions of the carapace posterior relative to the opisthosoma and in the slight enlargement of the third tergite. 'Kasibelunurus' randalli (Beecher, 1902) shares with both true Kasibelinurus species the possession of the crescentic carapace and $\mathrm{H}$ shaped cardiac lobe but lacks the enlarged pretelson, while it also possesses ophthalmic ridges that meet medially to form a double arch configuration, which is the plesiomorphic condition in xiphosurids (Selden \& Siveter, 1987). Xiphosurids also possess a crescentic carapace and precardiac field, which serves to unite both Kasibelinurus species and 'Kasibelinurus' randalli with Xiphosurida to the exclusion of all other synziphosurines. 'Kasibelinurus' randalli is further linked to xiphosurids in the shared possession of medially converging ophthalmic ridges, converging ophthalmic ridges being a characteristic absent from the two Kasibelinurus species and all other synziphosurines. Kasibelinurus amicorum and Kasibelinurus yueya would therefore form the sisterclade to a group comprising 'Kasibelinurus' randalli and xiphosurids. A full redescription of the available material of 'Kasibelinurus' randalli is needed before its position relative to xiphosurids can be properly ascertained, however. The two true Kasibelinurus species meanwhile are clearly differentiated from xiphosurids by their freely articulating thoracic segments. Kasibelinurus was originally linked to xiphosurids through the supposed characteristic of having only nine opisthosomal segments (Anderson \& Selden, 1997); however, Kasibelinurus yueya has an opisthosoma consisting of ten segments, with the anterior-most being partly obscured by the carapace posterior margin. An anterior tergite in this position can also be seen in the holotype of Kasibelinurus amicorum (Pickett, 1993, fig. 3), resulting in this species also having an opisthosomal count of ten segments. This does not contradict the proposed link to xiphosurids, however, as the earliest xiphosurids have been shown to also possess ten opisthosomal segments (Rudkin, Young \& Nowlan, 2008).
Little can be deduced about the palaeoecology of Kasibelinurus yueya. The palaeoenvironment of synziphosurines is almost exclusively marginal marine (Moore, McKenzie \& Lieberman, 2007), and the marine tidal flat habitat of the Xiaxishancun Formation concurs with this. Synziphosurines have been shown to leave distinctive trace fossils produced by shallow furrowing in the sediment (Babcock et al. 1995). Anderson, Poschmann \& Brauckmann (1998) mentioned an undescribed specimen of 'Kasibelinurus' randalli from the Upper Devonian of Pennsylvania that showed enrollment. The morphology of Kasibelinurus yueya is not greatly different from 'Kasibelinurus' randalli and basal xiphosurids, so it is likely that it, too, furrowed in the sediment for food, and could enroll when physical or biotic dangers threatened.

Kasibelinurids are now known from the Upper Devonian of Australia (palaeocontinent), the Lower Devonian of the South China Block (SCB, herein), and possibly the Upper Devonian of Pennsylvania (Babcock et al. 1995). Regarding the palaeobiogeographic connection between the two confirmed members of the family, the proximity of Australia and the SCB during the Devonian has been debated (Torsvik \& Cocks, 2009). In palaeogeographic reconstructions, the SCB is usually placed off NW Australia, but whether it was attached to Gondwana or separated in the early Palaeozoic is unclear. On the most recent reconstructions (e.g. Torsvik \& Cocks, 2009; Young et al. 2010), the SCB is separated from Gondwana by ocean throughout the early Palaeozoic up to the Devonian. On the contrary, Yang et al. (2004) placed the two palaeocontinents in close proximity, primarily based on palaeomagnetic data. Of course, kasibelinurids are likely to have shown planktotrophic development as in modern xiphosurids, so a narrow ocean would have provided no barrier to dispersal between these landmasses. The similarity, however, of terrestrial floras between the SCB and Australia in the mid-Palaeozoic indicates that these two areas had much in common floristically (Hao \& Gensel, 1998, 2001).

Acknowledgements. PAS thanks an Alexander von Humboldt Foundation Research Award. JZX was supported by the National Natural Science Foundation of China (No. 41272018). JCL thanks Amanda Falk (University of Kansas) for assisting with Chinese translations. The authors thank Prof. Shougang Hao (Peking University), with whom JZX collected the fossil in 2006.

\section{References}

Anderson, L. I., Poschmann, M. \& Brauckmann, C. 1998. On the Emsian (Lower Devonian) arthropods of the Rhenish Slate Mountains: 2. The synziphosurine Willwerathia. Paläontologische Zeitschrift 72, 325-36.

ANDERSON, L. I. \& SELDEN, P. A. 1997. Opisthosomal fusion and phylogeny of Palaeozoic Xiphosura. Lethaia 30, 1931.

BABCoCK, L. E., Wegweiser, M. D., Wegweiser, A. E., StAnley, T. M. \& MCKenZIE, S. C.1995. Horseshoe crabs and their trace fossils from the Devonian of Pennsylvania. Pennsylvania Geology 26, 2-7.

BEECHER, C. E. 1902. Note on a new xiphosuran from the Upper Devonian of Pennsylvania. American Geologist 29, 143-6.

CAI, C.-Y., FANG, Z.-J., LI, X.-X., WANG, Y., GENG, L.-Y., GAO, L.-D., WANG, N.-Z., LI, D.-Y. \& LIU, Z.-H. 1994. New advance in the study of biostratigraphy of Lower and Middle Devonian marine-continental transitional strata in east Yunnan. Science in China (Series B) 24, 634-9 (in Chinese). 
CAI, C.-Y. \& WANG, Y. 1995. Devonian floras. In Fossil Floras of China Through the Geological Ages (ed. X. X. Li), pp. 28-77. Guangzhou: Guangdong Science and Technology Press.

DunloP, J. A. \& SELDEN, P. A. 1997. The early history and phylogeny of the chelicerates. In Arthropod Relationships (eds R. A. Fortey \& R. H. Thomas), pp. 221-35. Systematics Association Special Volumes Series, no. 55.

DuPRET, V. \& ZHU, M. 2008. The earliest phyllolepid (Placodermi, Arthrodira) from the Late Lochkovian (Early Devonian) of Yunnan (South China). Geological Magazine 145, 257-78.

ELDREDGE, N. 1974 Revision of the Suborder Synziphosurina (Chelicerata, Merostomata), with remarks on merostome phylogeny. American Museum Novitates 2543, 1-41.

ELLER, E. R. 1938. A review of the xiphosuran genus Belinurus with the description of a new species, $B$. allegayensis. Annals of the Carnegie Museum 27, 12950.

Eller, E. R. 1940. Belinurus carteri a new xiphosuran from the Upper Devonian of Pennsylvania. Annals of the Carnegie Museum 28, 133-6.

FANG, Z.-J., CAI, C.-Y., WANG, Y., LI, X.-X., WANG, C.-Y., GENG, L.-Y., WANG, S.-Q., GAO, L.-D., WANG, N.-Z. \& LI, D.-Y. 1994. New advance in the study of the Silurian-Devonian boundary in Qujing, east Yunnan. Journal of Stratigraphy 18, 81-90 (in Chinese with English abstract).

HaO, S.-G. \& GENSEL, P. G. 1998. Some new plant finds from the Posongchong Formation of Yunnan, and consideration of a phytogeographic similarity between South China and Australia during the Early Devonian. Science in China (series D) 41, 1-13.

HaO, S-G. \& Gensel, P. G. 2001. The Posongchong floral assemblages of southeastern Yunnan, China: diversity and disparity in Early Devonian plant assemblages. In Plants Invade the Land: Evolutionary and Environmental Perspectives (eds P. G. Gensel \& D. Edwards), pp. 103-19. New York: Columbia University Press.

HaO, S.-G., XUE, J.-Z., LIU, Z.-F. \& WANG, D.-M. 2007. Zosterophyllum Penhallow around the Silurian-Devonian boundary of Northeastern Yunnan, China. International Journal of Plant Sciences 168, 477-89.

HeYmons, R. 1901. Die Entwicklungsgeschichte der Scolopender. Zoologica (Stuttgart) 13, 1-244.

Latreille, P. A. 1802. Histoire naturelle, générale et particulière, des Crustacés et des Insectes, vol. 3. Paris: Dufart, $467 \mathrm{pp}$.

LI, X.-X. \& CAI, C.-Y. 1978. A type section of Lower Devonian strata in Southwest China with brief notes on the succession and correlation of its plant assemblages. Acta Geologica Sinica 52, 1-12 (in Chinese with English abstract).

LiU, Z.-F., HAO, S.-G., WANG, D.-M. \& LIU, J.-B. 2004. Study on the Xujiachong Formation section of nonmarine Lower Devonian of eastern Yunnan, China. In Professional Papers of Stratigraphy and Palaeontology 28 (ed. Editorial Committee of Professional Papers of Stratigraphy and Palaeontology, Chinese Academy of Geological Sciences), pp. 61-88. Beijing: Geological Publishing House.

Moore, R. A., McKenzie, S. C. \& Lieberman, B. S. 2007. A Carboniferous synziphosurine (Xiphosura) from the
Bear Gulch Limestone, Montana, USA. Palaeontology 50, 1013-19.

PICKETT, J. W. 1993. A Late Devonian xiphosuran from near Parkes, New South Wales. Memoirs of the Association of Australian Palaeontologists 15, 279-87.

RonG, J.-Y. \& CHEN, X. 2000. Comments on Silurian chronostratigraphy of China. Journal of Stratigraphy 24, 27-35 (in Chinese with English abstract).

Rudkin, D. M., Young, G. A. \& Nowlan, G. S. 2008. The oldest horseshoe crab: a new xiphosurid from late Ordovician Konservat-Lagerstätten deposits, Manitoba, Canada. Palaeontology 51, 1-9.

SCOTESE, C. R. \& MCKERROW, W. S. 1990. Revised world maps and introduction. In Palaeozoic Palaeogeography and Biogeography (eds W. S. McKerrow \& C. R. Scotese), pp. 1-21. Geological Society of London, Memoir no. 12

Selden, P. A. \& Siveter, D. J. 1987. The origin of the limuloids. Lethaia 20, 383-92.

Tian, J.-J., ZHU, H.-C., HuAng, M. \& LiU, F. 2011. Late Silurian to Early Devonian palynomorphs from Qujing, Yunnan, southwest China. Acta Geologica Sinica English Edition 85, 559-68.

TorsviK, T. H. \& COCKS, L. R. M. 2009. The Lower Palaeozoic palaeogeographical evolution of the northeastern and eastern peri-Gondwanan margin from Turkey to New Zealand. In Early Palaeozoic PeriGondwana Terranes: New Insights from Tectonics and Biogeography (ed. M. G. Bassett), pp. 3-21. Geological Society of London, Special Publication no. 325.

VAN ROY, P., ORR, P. J., BOTTING, J. P., MUIR, L. A., VINTHER, J., Lefebvre, B., El Hariri, K. \& BriggS, D. E. G. 2010. Ordovician faunas of Burgess Shale type. Nature 465, 215-18.

WANG, N.-Z. 1997. Restudy of thelodont microfossils from the lower part of the Cuifengshan Group of Qujing, eastern Yunnan, China. Vertebrata Palasiatica 35, 1-17 (in Chinese with English summary).

WANG, S.-Q., LIU, Z.-M. \& LI, Z.-B. 1992. Late Silurian and Early Devonian ostracodes from the Qujing area, Yunnan. Acta Micropalaeontologica Sinica 9, 363-89 (in Chinese with English summary).

XUE, J.-Z. 2012. Lochkovian plants from the Xitun Formation of Yunnan, China, and their palaeophytogeographical significance. Geological Magazine 149, 333-44.

YANG, Z-Y., Sun, Z-M., YANG, T-S. \& PEI, J-L. 2004. A long connection (750-380 Ma) between South China and Australia: paleomagnetic constraints. Earth and Planetary Science Letters 220, 423-34.

Young, G. C., Burrow, C. J., Long, J. A., Turner, S. \& CHOO, B. 2010. Devonian macrovertebrate assemblages and biogeography of East Gondwana (Australasia, Antarctica). Palaeoworld 19, 55-74

Zhang, Q-Y., Hu, S-X., ZHoU, C-Y., Lv, T. \& BAI, J-K. 2009. [New occurrence of Xiphosura in China.] Progress in Nature Science 19, 1090-3. (in Chinese).

ZhaO, W.-J., WANG, N.-Z., ZhU, M., MANN, U., Herten, U. \& LÜCKE, A. 2011. Geochemical stratigraphy and microvertebrate assemblage sequences across the Silurian/Devonian transition in South China. Acta Geologica Sinica - English Edition 85, 340-53.

ZHAO, W.-J. \& ZHU, M. 2010. Siluro-Devonian vertebrate biostratigraphy and biogeography of China. Palaeoworld 19, 4-26. 
Reproduced with permission of the copyright owner. Further reproduction prohibited without permission. 